\title{
80-luvun näköaloja
}

Ilman ennustajanlahjojakin on helppo nähdä, että 1980-luku tulee olemaan suurten muutosten vuosikymmen. Maailmanrauhan uhanalaisuus, toisaalla nälänhätä ja toisaalla yltäkylläisyys, elinympäristömme saastuminen, työttömyys, yleinen vieraantuneisuus, poliittinen sorto ym. suuret ongelmat pakottavat meidät arvioimaan monia asioita uudelleen ja etsimään näihin ratkaisuja. Nämä ongelmat osoittavat myös ''kohtalonyhteytemme'" luonnon, eri kansakuntien ja ihmisten kanssa. Globaalinen näkökulma ja vastuunottaminen kansainvälisestä kehityksestä on hitaasti leviämässä myös suomalaiseen yhteiskuntaan. Myöskin kansallisella tasolla - poliittisessa, sosiaalisessa, kulttuuri- ja talouselämässä - pyritään asioiden tärkeysjärjestystä arvioimaan uudelleen aivan toisenlaisista näkökulmista kuin vielä 1970-luvulla. Mainittakoon tästä esimerkkinä suhtautuminen taloudelliseen kasvuideologiaan. Nykyisin yhä useammat suhtautuvat siihen kriittisesti ja yhä harvemmat uskovat sen ihmeitä tekevään voimaan elämän laadun parantajana.

Uudenlaisen ajattelun leviämisestä myös aikuiskasvatukseen on olemassa selviä merkkejä. 1960-luvun lopulla ja 1970-luvun alussa varsin vahvana esiintyneestä "hyötyajattelusta" ollaan siirtymässä moniarvoisempaan ja ihmisen kokonaispersoonallisuuden paremmin huomioon ottavaan suuntaan. Tämä "'henkisen kasvun" -suuntaus tullee edelleen voimistumaan 80-luvun edetessä. Tärkeätä olisi, että tämä ajattelu, jota esiintyy lähinnä vapaan sivistystyön piirissä, pääsisi juurtumaan myös työelämän aikuiskasvatukseen.

Edellä luetellut asiat ja ongelmat eivät saa olla aikuiskasvattajille - sen paremmin kuin muillekaan aikuisille - vieraita. Kansainvälisten ongelmien ja rauhanasian käsittely tulee sisällyttää kaikkien aikuiskasvatusorganisaatioiden ohjelmiin joko omina oppiaineina tai muiden oppiaineiden yhteyteen "läpäisyperiaatteella".

Eräs yleinen yhteiskuntamme kehityspiirre on sen teknistyminen ja automatisoituminen. Tätä kehitystä voimme tuskin estää. Sensijaan voimme vaikuttaa siihen, millä tavalla tämä kehitys toteutetaan. Tekninen kehitys ei ole yksinomaan "tekninen"' kysymys, vaan siinä on aina viime kädessä kysymys arvoista. Mm. Teknologiakomitea on korostanut aikuiskasvatuksen merkitystä tämän muutosprosessin toteuttamisessa. Sen perusteluina olivat tosin lähinnä erilaisten ammatillisten kvalifikaatioiden jatkuva uudistamistarve. Näiden tarpeiden tyydyttäminen on tietysti tärkeää, mutta se ei kuitenkaan yksistään riitä. Aikuiskasvatuksen tehtävänä on tarjota ihmisille myös tietoa tämän kehityksen eri vaihtoehdoista ja niihin liittyvistä arvokysymyksistä. 
Elämme parhaillaan suunnan etsimisen ja elämänarvojen uudelleenarvioinnin aikaa. Myös aikuiskasvatuksen piirissä on keskusteltava näistä asioista. Aikuiskasvatuksella on omien organisaatioidensa kautta hyvät mahdollisuudet laajentaa tämä keskustelu koko aikuisväestöä käsittäväksi vuoropuheluksi.

Kun aikuiskasvatuksen alkuvaiheessa - kansanvalistuksen aikana noin sata vuotta sitten toiminnan keskeisenä tavoitteena oli kansallisen kulttuurin ja identiteetin luominen, niin tällä hetkellä aikuiskasvatuksen eräänä keskeisenä tehtävänä voidaan pitää Suomen kansan herättämistä kansainväliseen ajatteluun ja näkemään oman vastuunsa - yhtenä maailman hyvinvointivaltiona - köyhien maanosien ja kansojen auttamisessa.

Aikuiskasvatus -lehteä on nyt ilmestynyt kolme numeroa. Näiden perusteella lukijat voivat päätellä jo jotain lehden 'linjasta'. Saamamme palautteen perusteella näyttää siltä, että lehti täyttää todella tietyn aukon aikuiskavatuksen kentässä. Sen tarpeellisuudesta ovat olleet kaikki yhtä mieltä.

Lehden tulevaisuus näyttää valoisalta. Tilaajia on tullut melko mukavasti. Tosin tässä on edelleen parantamisen varaa. Lehden talous on myös turvattu ainakin ensi vuodeksi, sillä tilaustulojen lisäksi lehdellä on käytettävissään apuraha, jonka Suomen Akatemia myönsi lehden toimittamista varten. Kirjoittajia on myös riittänyt, niin että lehden kokoamisessa ei ole ollut vaikeuksia. Tässä yhteydessä on tosin hyvä palauttaa mieleen ensimmäisessä numerossa esitetty "'ohjelma", jonka mukaan lehdessä pyritään lähentämään teoriaa ja käytäntöä keskenään sekä käymään monipuolista keskustelua alan kehittämistoiminnasta. 'Kenttäväenkään'” ei siis tarvitse vierastaa lehden 'tieteellisyyttä". Vaikka lehteen pyritäänkin saamaan aina joku tai joitakin vaatimammat mitat täyttäviä artikkeleita, niin lehden toimitus ottaa mielellään vastaan myös sellaisia kirjoituksia, joissa alan ongelmia lähestytään käytännöllisemmästä kentän työntekijän näkökulmasta.

Erääksi tehtäväkseen lehden toimituskunta näkee keskustelun virittämisen parhaillaan käynnissä olevasta alan kehittämistoiminnasta. Lehdessä onkin ollut joitakin kehittämistoiminnan nykytilaa käsittäviä uutisjuttuja, mutta kehittämistoiminnan periaatteellisista kysymyksistä ei kuitenkaan ole vielä saatu keskustelua käynnistymään. Kenen tehtävä se tulisi olla? Epäilemättä niiden, joilla on tästä toiminnasta lähempää tietoa. Ilmeisesti ainoa kehittämisorganisaation taholta julkisuudessa esitetty kehittämistyön periaatteellisiin kysymyksiin paneutuva puheenvuoro oli Reijo Käkelän Opistolehdessä (4/1981) ollut artikkeli ''Uudenlaiseen aikuiskoulutuksen suunnitteluun". Toivottavasti keskustelu tulevaisuudessa laajenee. 